\title{
OBSERVATIONS ON L-FORMS OF YERSINIA ENTEROCOLITICA
}

\author{
Phyllis Pease \\ Department of Medical Microbiology, University of Birmingham, Birmingham B15 2TJ \\ Plates XVII-XXI
}

IN recent years Yersinia enterocolitica has attracted a great deal of attention, especially in Scandinavian countries, mainly because of its association with pathological conditions such as terminal ileitis, enteritis and reactive arthritis (Larsen, 1976). Numerous studies have been conducted upon the cultural, biochemical, serological and pathogenic properties of the organism, but so far there has been no report of the occurrence of L-forms.

In cultures of $Y$. enterocolitica in this laboratory, L-form-like organisms were observed to occur spontaneously, and it is the purpose of this paper to describe them.

\section{MATERIALS AND METHODS}

Organisms. Three strains of Y. enterocolitica, NCTC nos. 10460, 10461, and 10462, were obtained from the National Collection of Type Cultures, Colindale, London.

Culture media. Cultures were made on Difco Tryptose Blood Agar Base, Difco MacConkey Agar without crystal violet, and in Difco Brain Heart Infusion Broth.

Phase-contrast microscopy. Blocks of agar bearing colonies were cut out and placed on slides with colonies uppermost and observed directly, at low magnification, by means of a Wild phase-contrast microscope. For oil-immersion examination, coverslips were placed over the colonies.

Biochemical reactions were performed according to the methods of Cowan and Steel (1974). Where more than one method is described, the following were chosen: catalase, method 1; oxidase, 1; nitrate reduction, 1; urease, $1 ; \mathrm{H}_{2} \mathrm{~S}, 3$; indole, 2; Voges Proskauer, 2; gelatin hydrolysis, 5; arginine, ornithine, and lysine decarboxylase, 2.

Agglutination tests. Slide and Widal-type tests were performed. Antigens for agglutination tests were prepared from organisms grown at $37^{\circ} \mathrm{C}$ or room temperature overnight. They were steamed for $30 \mathrm{~min}$. and washed three times in saline. The deposits were then resuspended in $5 \mathrm{ml}$ of saline and heated at $100^{\circ} \mathrm{C}$ for $10 \mathrm{~min}$. These suspensions were then further diluted in saline to the opacity, as measured by eye, of a standard suspension of $Y$. enterocolitica, which had been made up previously and was known to give satisfactory results in agglutination tests. The tests were done in haemagglutination trays with doubling dilutions of antiserum, and readings were taken after $4 \mathrm{~h}$ at $22^{\circ} \mathrm{C}$. Slide-agglutination tests were examined by phase-contrast microscopy.

Gel-diffusion tests. Antigens for use in gel-diffusion tests were prepared as for agglutination, except that the suspensions were 200 times stronger, and were subjected to ultrasonic disintegration for 5-10 min. at $20 \mathrm{kc} / \mathrm{sec}$. Tests were by double-diffusion precipitation in ion-agar gel containing sodium azide $1 \mathrm{~g}$, Ion Agar No. 2(Oxoid) $10 \mathrm{~g}$, and saline $(0.85 \%$ w.v. in water) $1000 \mathrm{ml}$.

Fluorescent-antibody tests. Impression preparations of colonies or smears of the organisms

Received 17 Aug. 1978; accepted 11 Jan. 1979.

J. MED. MICROBIOL. - VOL. 12 (1979) 
were made on slides and heat-fixed. They were covered with antiserum or pre-immunisation serum, left for 15 min., washed in Oxoid Phosphate Buffered Saline (PBS) for 15-30 min., covered with sheep anti-rabbit globulin fluorescin conjugate (Progressive Laboratories Baltimore Inc., Baltimore, USA) for 15 min., washed in PBS for 15-30 min. and then mounted in $50 \%$ $(\mathrm{v} / \mathrm{v})$ glycerol in PBS.

Antisera. Organisms from $500-\mathrm{ml}$ amounts of broth culture were resuspended in $10 \mathrm{ml}$ of saline after heat treatment at $100^{\circ} \mathrm{C}$ for $10 \mathrm{~min}$. or treatment with $0.2 \%$ formalin for a minimum of $48 \mathrm{~h} ; 2 \times 1 \mathrm{ml}$ of the suspension were injected into rabbits subcutaneously at weekly intervals for 5-6 weeks.

Electron microscopy (EM). Organisms were scraped from the surface of agar or centrifuged from broth cultures; they were fixed at room temperature for $30 \mathrm{~min}$. in $2.5 \%$ gluteraldehyde in $0.05 \mathrm{M}$ phosphate buffer at $p \mathrm{H} 7 \cdot 2-7 \cdot 4$, containing $0.05 \mathrm{M}$ sucrose, then post-fixed in $1.0 \%$ osmic acid in the same buffer for $2 \mathrm{~h}$ at $4^{\circ} \mathrm{C}$, followed by routine dehydration and embedding in Epon. Sections were cut on a Sorval-Porter Blum MT-2 ultramicrotome, stained with uranyl acetate and lead citrate and examined in a Philips EM301 electron microscope.

\section{RESULTS}

\section{Isolation of $L$-forms}

In cultures of $Y$. enterocolitica strain NCTC10460, papillary secondary colonies consisting of pleomorphic forms were regularly observed within colonies aged 2-3 weeks. The two phases were not easy to separate, but on occasion subcultures from the papillae on MacConkey agar apparently consisted entirely of gram-negative coccal forms. On further incubation of these subcultures for 3-4 days gram-negative rods reappeared. When subcultures were made on MacConkey agar or tryptose blood-agar base, coccal forms were present after 12-24 $\mathrm{h}$ and later rod-forms appeared. This was observed manv times during a period of 6 months.

\section{Phase-contrast microscopy}

On incubation at $37^{\circ} \mathrm{C}$ for $12 \mathrm{~h}$, subcultures from any stages in the developmental cycle gave rise to small colonies of coccal forms, usually $2-3 \mu \mathrm{m}$ but occasionally as large as $6.0 \mu \mathrm{m}$ in diameter. These forms were subsequently identified as large spheroplast L-forms and will be referred to as such for the remainder of this paper. At this stage the small colonies resembled classical L-form colonies in that the organisms of which they consisted were rounded and of ten vesiculated (fig. 1) but macroscopically they did not have a 'fried-egg' appearance. On further incubation for 12-48 h, smaller coccal forms $0 \cdot 5-1 \cdot 0$ $\mu \mathrm{m}$ in diameter, some of which were shown by electron microscopy to be small spheroplasts and some to be small bacterial forms (fig. 2) appeared. The latter forms seemed to represent a stage in the reversion process to the rod-form (see below). Because it was not possible to separate the small coccal forms from the large spheroplast L-forms by plating out, this two-phase stage, where appropriate, will be referred to as the large spheroplast L-form/small coccal-form (SLCF) stage.

At room temperature, the reversion process appeared to be different, in that the reverting forms were mostly tadpole-shaped, occurring at the edges of 
the large spheroplast colonies after incubation for 12-24 h (figs. 3 and 4). At this temperature the tadpole-shaped and the coccal forms were actively motile; the latter were non-motile at $37^{\circ} \mathrm{C}$.

After $48-72 \mathrm{~h}$ at $37^{\circ} \mathrm{C}$ and at room temperature, rod-forms resembling $Y$. enterocolitica strain NCTC10460 biochemically, serologically and, to some extent, morphologically, appeared at the edges of the colonies (fig. 5). Subcultures from this or any other part of the colonies produced large spheroplast L-forms and the cycle was repeated. Subculture into broth yielded mainly large spheroplast L-forms and small coccal forms (fig. 6) which tended to stay in this form, although occasional organisms of either type were seen to give rise to rod-forms (fig. 7). Again, motility was demonstrable at room temperature but not at $37^{\circ} \mathrm{C}$.

After 3 months of subculturing, another type of growth was observed on subculture on solid medium. As already observed in fluid medium, the large spheroplast L-forms were capable of producing rod-forms directly (fig. 4) and this process sometimes produced growth consisting of organisms resembling Streptobacillus moniliformis; these were composed of filaments and swollen elements (fig. 8). This type of growth maintained the same morphology during many weeks of daily subculture.

As already emphasised, subcultures of any stage of the cycle including apparently revertant rod-forms usually gave rise to large spheroplast L-forms. Repeated subculture from the edges of colonies where there was profuse growth of such rod-forms eventually resulted in successful isolation of the rod-forms. However, careful observation always revealed a few large spheroplast L-forms among the rods (fig. 9). Revertant forms and parental forms were never entirely free from large spheroplast L-forms and close examination of apparently normal colonies of the other strains (NCTC nos. 10461 and 10462) of $Y$. enterocolitica revealed very occasional spheroplast forms.

\section{Electron microscopy}

Cultures were grown under the same conditions as those used for phasecontrast microscopy. Sections of parent bacteria, large spheroplast L-forms, small coccal forms and revertant bacteria were examined. Figs. 10-12 are low-magnification electron micrographs of normal bacteria, large spheroplast L-forms and reverting bacteria, respectively. It is apparent that the large spheroplast L-forms are swollen and that the revertant bacteria have irregular contours compared with the parent bacteria. Characteristic appearances of the cell wall of the parent bacteria are shown in figs. 13 and 14. In fig. 13 the cell wall is shown to be adhering to the cell membrane, whereas in fig. 14 it has split away. The latter appearance was characteristic of the large spheroplast L-forms except for a minority of organisms that possessed only a single membrane (fig. 15) and could therefore be designated as protoplast L-forms. Thus the majority of L-forms retained cell-wall material and this, with their behaviour and further structural evidence to be discussed below, justifies their identification as spheroplast L-forms. 
Apart from the difference in contour regularity already noted, no structural differences were detected between the cell-walls of parent and revertant rodshaped bacteria. In the case of some of the small coccal forms a thickened cell wall, adherent to the cytoplasmic membrane, was observed (fig. 16). At the same time many of the small coccal forms had cell-wall appearances indistinguishable from those of the large spheroplast L-forms. A feature common to large and to small forms was the presence of membranes separating small cells, of ten containing compressed cytoplasm, from the main cell (fig. 17). It was not established whether some of these small cells were homologous with the tails of the tadpole-shaped organisms, representing a stage towards the development of the rod form but this seemed probable, particularly because the culture from which these preparations were taken was incubated at room temperature. Occasionally, it seemed that these cells were budded off and behaving like mini-cells (fig. 18).

The large spheroplast $\mathrm{L}$-forms showed other interesting features. Some cells had granular structures, ranging from 0.06 to $0.2 \mu \mathrm{m}$ in size, between the cytoplasmic membrane and the cell wall (fig. 19), and membranous structures probably situated in the vesicular regions seen in phase-contrast preparations (fig. 1) could be seen in some cells (fig. 20). Cells containing membranous structures and particulate matter (fig. 21) were particularly spectacular and probably represent mother cells, the particles being elementary bodies which, when shed, may have a reproductive potential. In some cells the membranous material was arranged in more organised form. Figs 22 and 23 show membranes of different thicknesses within different spheroplast L-cells and fig. 24 shows such membranes arranged in concentric circles within the same cell. Higher magnifications of some of these membranous structures with a range of thicknesses from 8.0 to $30.0 \mathrm{~nm}$ are shown in figs 25 and 26. The structure shown in fig. 27 appears to be tubular.

Another point of interest was the presence of fibrillar structures within the large spheroplast L-cells. These most often occurred singly (fig. 28) but sometimes two or three were observed in one cell (fig. 29). They ranged from $200 \mathrm{~nm}$ to $1.2 \mathrm{~m} \mu$ in length. Fig. 30 shows a bundle of fibrils and fig. 31 shows an enlargement of an area similar to the structures in fig. 29 with particulate material and fibrils. Fig. 32 is an enlargement of part of fig. 28 showing undulated fibrils with a wavelength of $c .30 \mathrm{~nm}$.

\section{Biochemical reactions}

These were determined at $37^{\circ} \mathrm{C}$ and at room temperature on 48-h cultures of $Y$. enterocolitica strains NCTC10460, 10461 and 10462, on 24-h cultures of SLCFs, on 24-h cultures of the streptobacillus phase and on 24-h cultures of reverted rod-forms containing very few large spheroplast forms. All the tests listed by Cowan and Steel (1974) for the identification of Y. enterocolitica were done on several occasions and all the forms tested showed the reactions characteristic of $Y$. enterocolitica. No marked difference was seen between tests done at $37^{\circ} \mathrm{C}$ and at room temperature, except in respect of the Voges- 
Proskauer (VP) reaction; this is usually positive at room temperature and negative at $37^{\circ} \mathrm{C}$ for $Y$. enterocolitica (Cowan and Steel, 1974). The parent strain (NCTC10460) was VP negative at both temperatures, whereas the large spheroplast L-form/small coccal-form cultures were positive at room temperature and negative at $37^{\circ} \mathrm{C}$. The revertant rods had a tendency when inoculated into fluid medium to give rise to large spheroplast L-forms and small coccal forms which gave positive VP reactions at room temperature; on two occasions when the rod-form persisted, the reaction was negative at both temperatures, as in the parent form.

\section{Agglutination tests}

Antisera were prepared to the parent $Y$. enterocolitica strain NCTC10460 incubated at $37^{\circ} \mathrm{C}$ and at room temperature (RT), to its SLCF stage grown at $37^{\circ} \mathrm{C}$ and to $Y$. enterocolitica strain NCTC10462 grown at $37^{\circ} \mathrm{C}$. These were tested against their homologous antigens grown at $37^{\circ} \mathrm{C}$ and room temperature and also against revertant bacteria. Slide-agglutination tests were also performed with organisms from cultures on solid medium. The results of the quantitative agglutination tests are shown in table $I$ and it can be seen that the SLCF cross-reacted with its parent strain, its own revertants and $Y$. enterocolitica strain NCTC10462. The reason for the differences in titre with organisms grown at different temperatures was not investigated. The organisms also cross-reacted in slide tests. By means of phase-contrast microscopy it was possible to observe the agglutination of the individual large spheroplast L-forms as well as of the small coccal forms with antiserum to the parent bacterial form, thus showing that both forms, which were inseparable by conventional bacteriological methods for the purposes of antigen preparation, were related serologically to one another as well as to the parent bacteria.

Control tests with pre-immunisation sera and with Staphylococcus aureus and Escherichia coli antigens gave no agglutination.

\section{Gel-diffusion tests}

These tests, by the occurrence of multiple lines of identity (fig. 33), also showed that the SLCF cross-reacts with its parent and revertant forms and with $Y$. enterocolitica strain NCTC10462. Again, no attempt was made to investigate differences in degrees of reaction with organisms incubated at different temperatures. Control tests with pre-immunisation sera and with dilutions of medium from 1 in 10 to 1 in 10000000 against antisera were negative. Streptobacillus moniliformis antigen also gave negative results with the test antisera.

\section{Fluorescent-antibody tests}

These were particularly useful in providing a means of simultaneously demonstrating morphological and serological relationships. Observations 


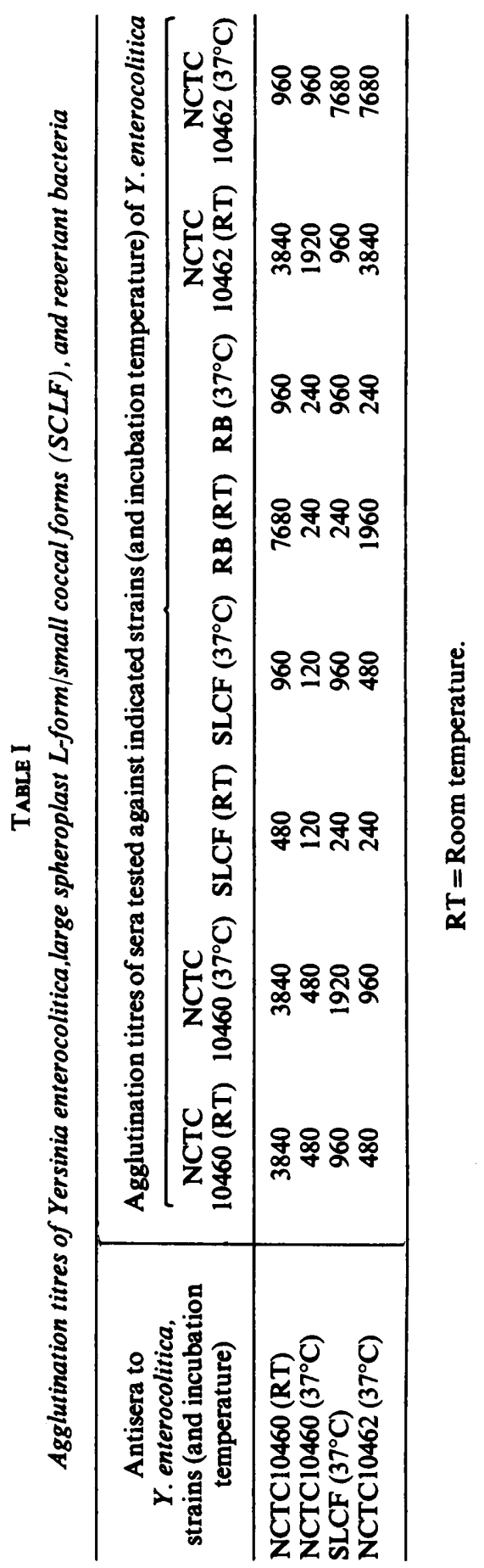



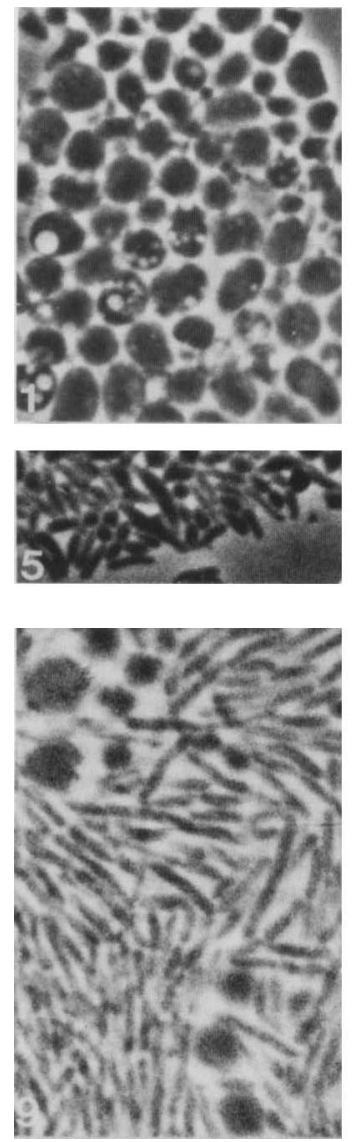
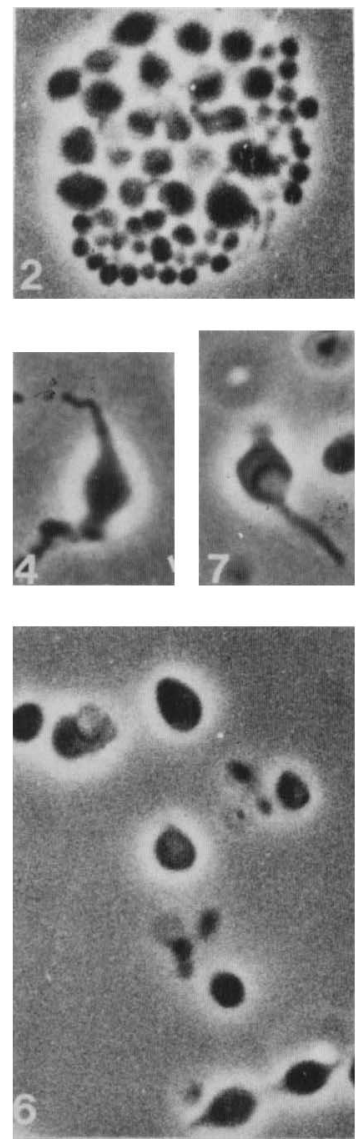
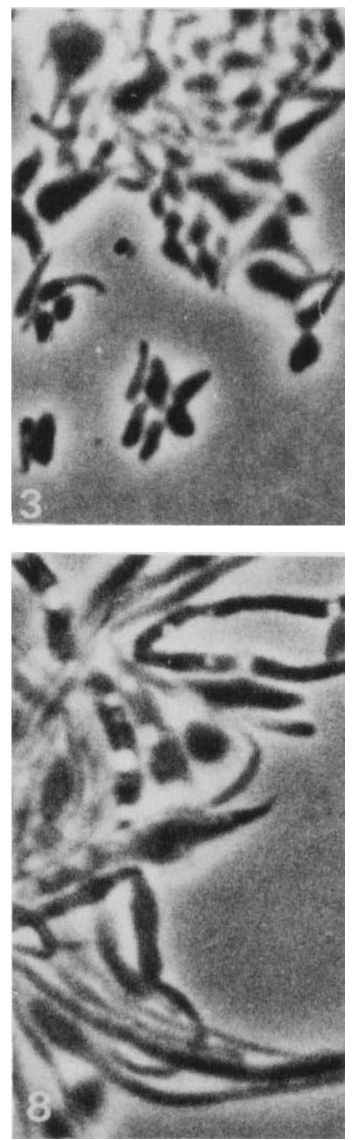

FIG. 1.-Large spheroplast L-forms in microcolony, $12 \mathrm{~h}$ at $37^{\circ} \mathrm{C}$. Phase contrast. $\times 3000$.

Fig. 2.-Large spheroplast L-form and small coccal forms, $12 \mathrm{~h}$ at $37^{\circ} \mathrm{C}$. Phase contrast. $\times 3000$.

FIGS. 3 and 4.--Tadpole-shaped forms incubated $12 \mathrm{~h}$ at room temperature. Phase contrast. $\times 3000$.

FIG. 5. - Revertant rod forms at colony edge, $48 \mathrm{~h}$ at $37^{\circ} \mathrm{C}$. Phase contrast. $\times 3000$.

Figs. 6 and 7.-Large spheroplast L-forms, incubated in fluid medium for $12 \mathrm{~h}$ at $37^{\circ} \mathrm{C}$. Phase contrast. $\times 3000$.

Fig. 8. - Streptobacillus form incubated $12 \mathrm{~h}$ at $37^{\circ} \mathrm{C}$. Phase contrast. $\times 3000$.

FIG. 9.- Reverted rod forms, incubated for $12 \mathrm{~h}$ at $37^{\circ} \mathrm{C}$. Phase contrast. $\times 3000$. 

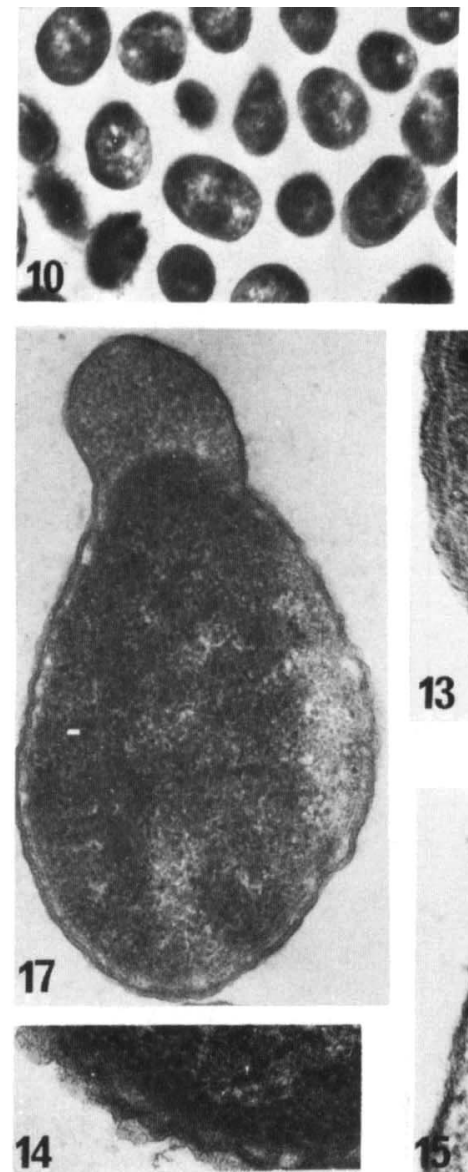
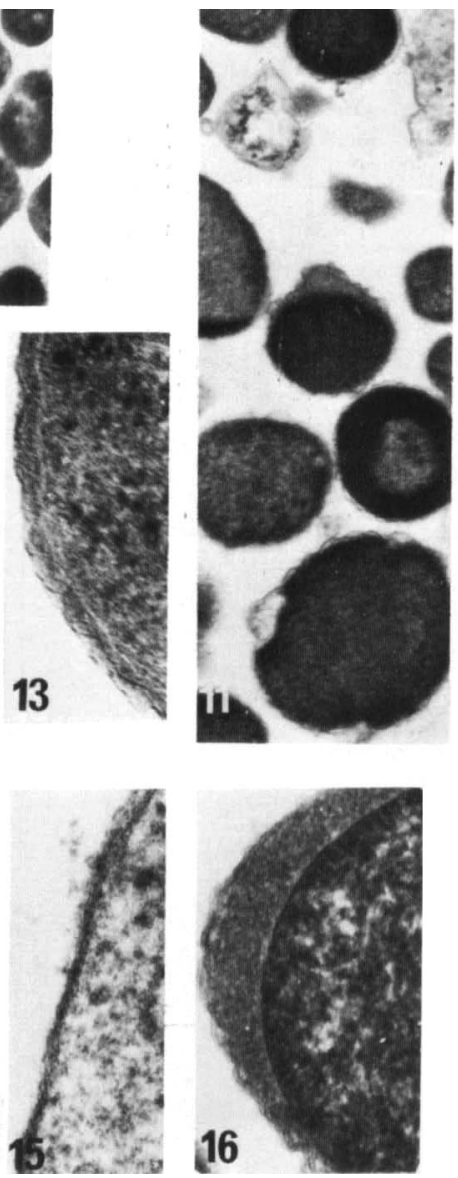

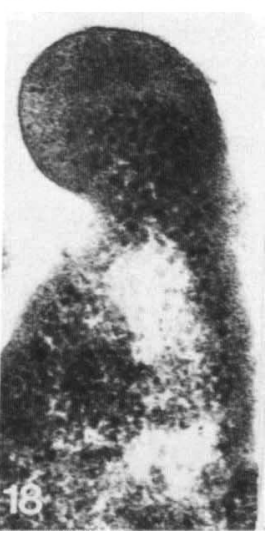

Fig. 10.-Parent rod form incubated for $12 \mathrm{~h}$ at $37^{\circ} \mathrm{C}$. Electron micrograph (EM) section. $\times 10200$.

FIG. 11.-Large spheroplast L-forms, incubated for $12 \mathrm{~h}$ at $37^{\circ} \mathrm{C}$. EM section. $\times 10200$.

FIG. 12.-Reverted rod forms incubated for $12 \mathrm{~h}$ at $37^{\circ} \mathrm{C}$. EM section. $\times 10200$.

Figs. 13 and 14.-Parent form incubated for $12 \mathrm{~h}$ at $37^{\circ} \mathrm{C}$. EM section. $\times 100000$.

Fig. 15.-Large protoplast L-form incubated for $12 \mathrm{~h}$ at room temperature. EM section. $\times 100000$ and 30000.

FIG. 16. -Small coccal form incubated for $24 \mathrm{~h}$ at $37^{\circ} \mathrm{C}$. EM section. $\times 50000$.

FIG. 17. - Small coccal form incubated for $48 \mathrm{~h}$ at room temperature in fluid medium. EM section. $\times 54000$. FIG. 18. - Large coccal form incubated for $48 \mathrm{~h}$ at room temperature in fluid medium. EM section. $\times 63000$. 

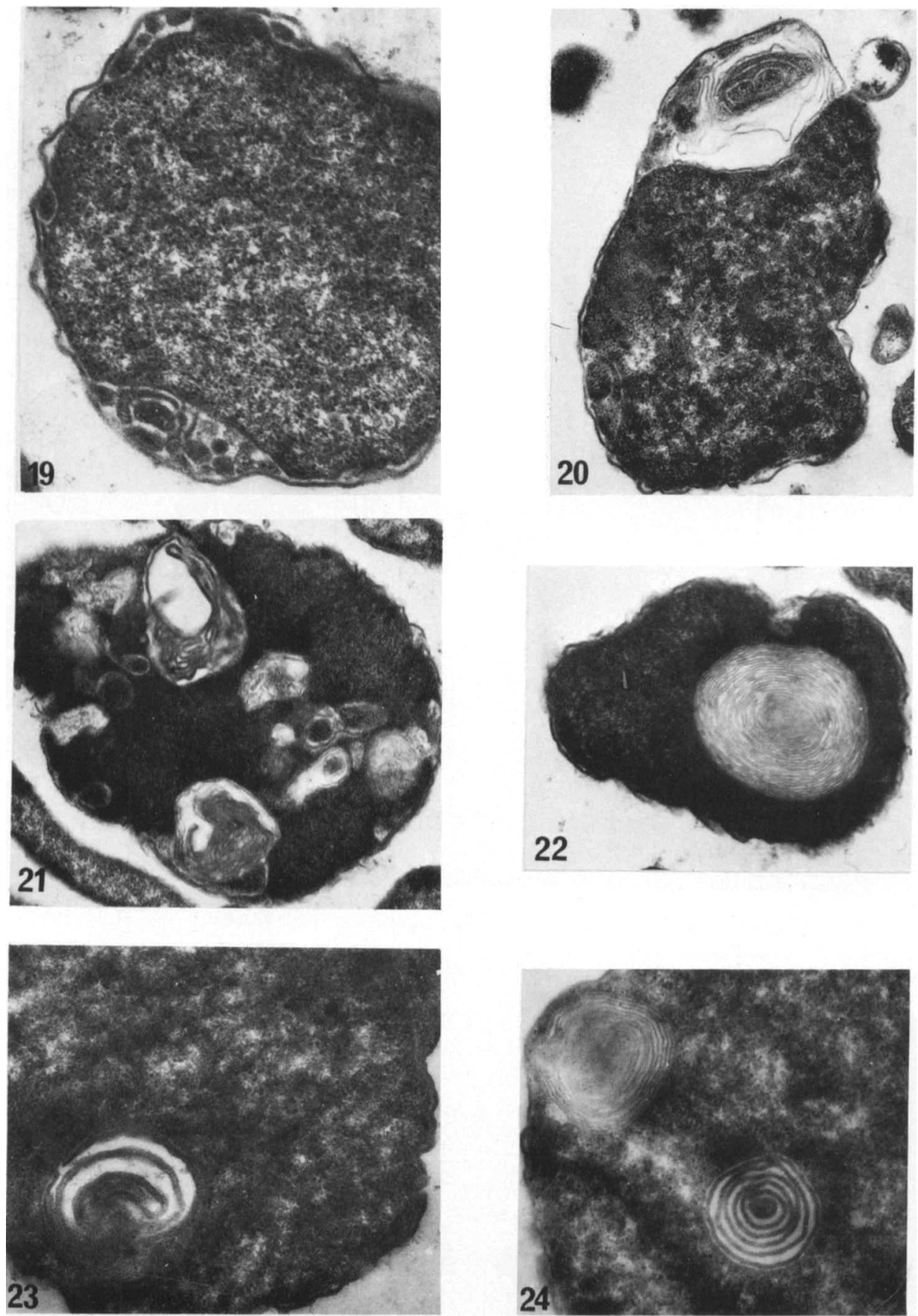

Fig. 19. - Large spheroplast $\mathrm{L}$-form incubated for $48 \mathrm{~h}$ at room temperature in fluid medium. EM section. $\times 32000$.

FIG. 20.- Large spheroplast $\mathrm{L}$-forms incubated for $48 \mathrm{~h}$ at room temperature in fluid medium. EM section. $\times 26000$.

FIG. 21.-Large spheroplast L-forms incubated for $21 \mathrm{~h}$ at room temperature. EM section. $\times 20000$.

Figs. 22-24. - Large spheroplast L-form incubated for $48 \mathrm{~h}$ at room temperature in fluid medium. EM sections. $\times 16000, \times 32000, \times 32000$. 


\section{L-FORMS OF YERSINIA}
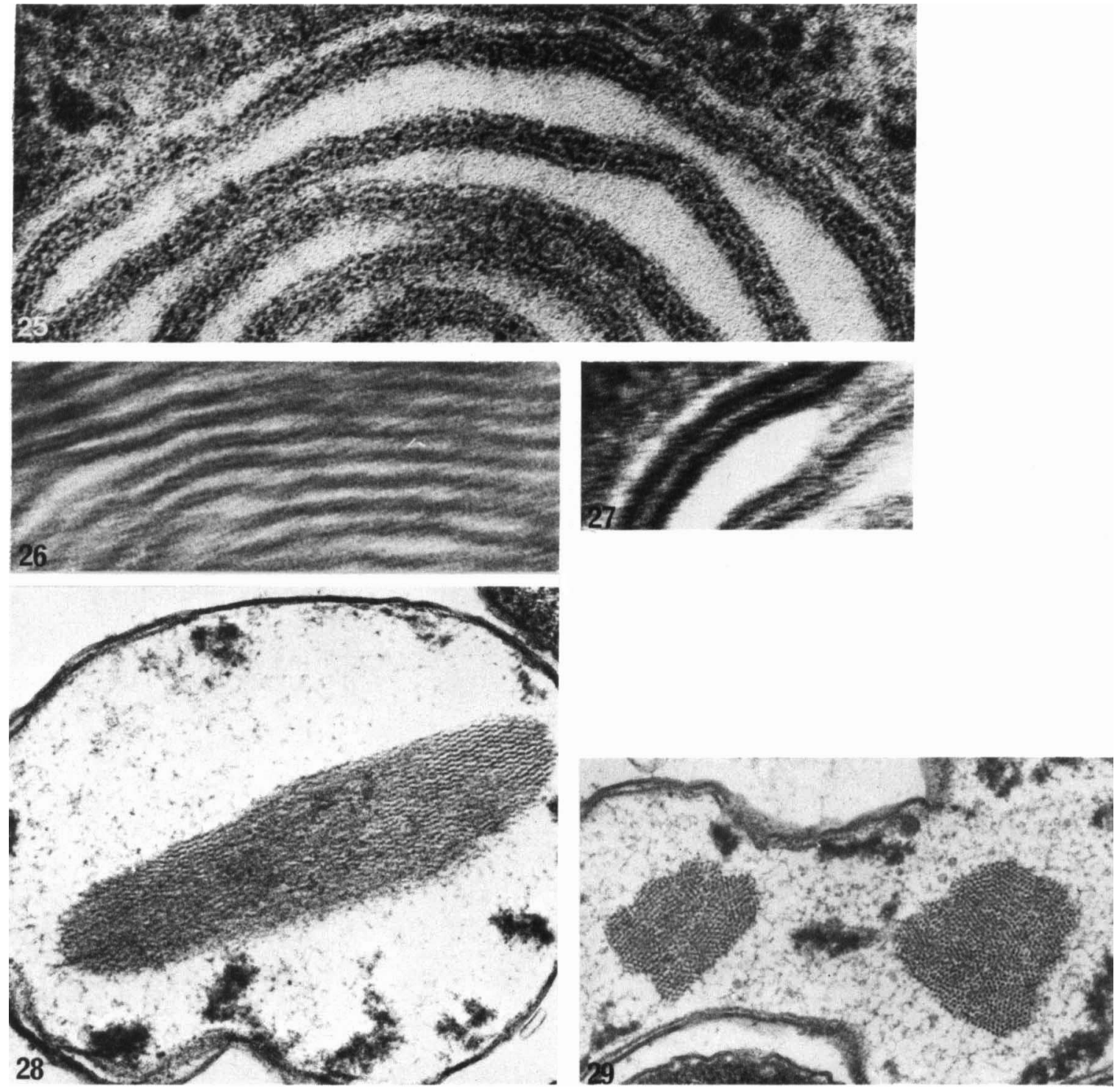

Figs. 25 and 26.--Enlargements from figs. 22 and $24 . \times 200000$.

Fig. 27.-Portion of tubular structure in large spheroplast L-form incubated for $12 \mathrm{~h}$ at room temperature. EM section. $\times 200000$.

FIGS. 28 and 29.-Large spheroplast L-form incubated for $24 \mathrm{~h}$ at $37^{\circ} \mathrm{C}$. EM sections. $\times 45000, \times 38000$. 

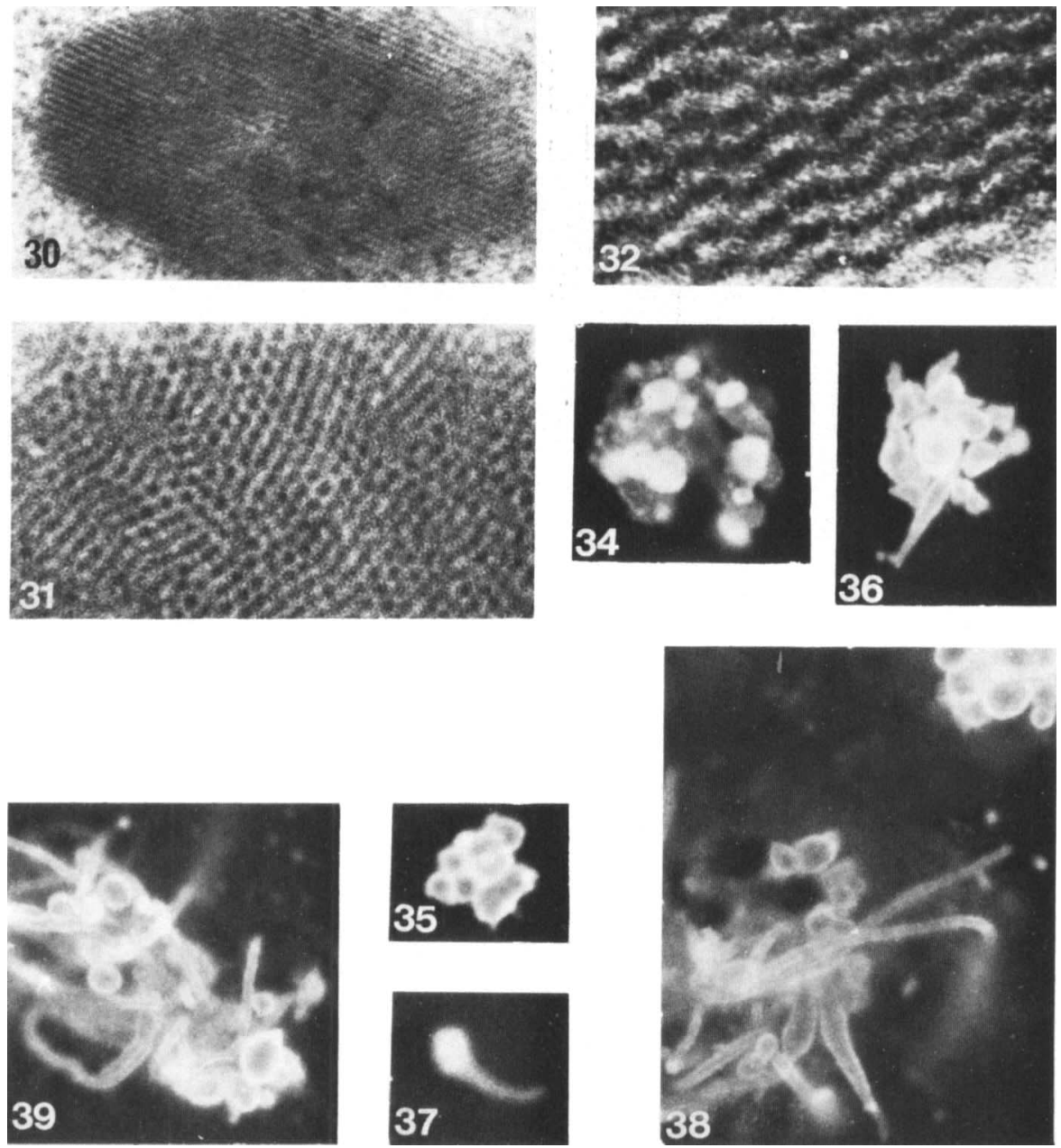

Figs. 30-32.-Portion of fibrillar material in large spheroplast L-form incubated at $37^{\circ} \mathrm{C}$ for $24 \mathrm{~h}$. EM sections. $\times 50000, \times 100000, \times 300000$.

Fig. 34-Impression preparation of large spheroplast L-form colony incubated at $37^{\circ} \mathrm{C}$ for $12 \mathrm{~h}$. Stained with fluorescent antibody and antibody to strain NCTC10460. $\times 3000$.

Fig. 35.--Impression preparations of small coccal forms incubated at $37^{\circ} \mathrm{C}$ for $24 \mathrm{~h}$. Stained as in fig. 34 . $\times 3000$.

FIG. 36.--Impression preparation of large spheroplast L-forms, small coccal forms and tadpole-shaped forms incubated at room temperature for $12 \mathrm{~h}$. Stained as in fig. $34 . \times 3000$.

FIG. 37.- Large spheroplast L-form producing rod-form, taken from culture incubated at $37^{\circ} \mathrm{C}$ for $12 \mathrm{~h}$. Stained as in fig. $34 . \times 3000$.

Figs. 38 and 39. - Impression preparations of streptobacillus stage showing coccal and rod forms, incubated at $37^{\circ} \mathrm{C}$ for $12 \mathrm{~h}$. Stained as in fig. $34 . \times 3000$. 


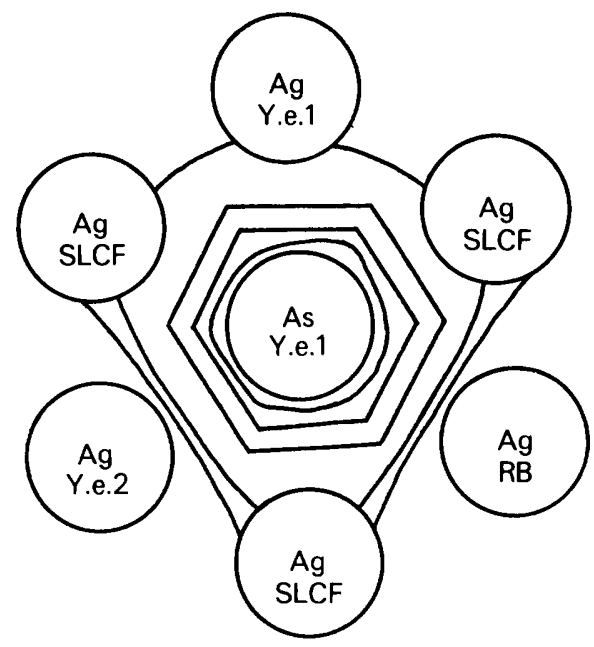

FIG. 33.--Gel-diffusion precipitin reactions. Antigens (Ag) of $Y$. enterocolitica strain NCTC10460 (Y.e.1), spheroplast L-form/small coccal forms (SLCF), revertant bacteria (RB) and Y. enterocolitica strain NCTC10462 (Y.e.2) against antiserum (As) to Y. enterocolitica strain NCTC10460.

TABLE II

Fluorescent antibody reactions of Yersinia enterocolitica, large spheroplast L-form/small coccal forms (SLCF) and revertant bacteria $(R B)$

\begin{tabular}{|c|c|c|c|c|}
\hline \multirow{2}{*}{$\begin{array}{l}\text { Antisera to } \\
\text { Y. enterocolitica } \\
\text { strains (and incubation } \\
\text { temperature) }\end{array}$} & \multicolumn{4}{|c|}{$\begin{array}{c}\text { Reaction of sera tested against indicated } \\
\text { strains (and incubation temperature) of } Y \text {. } \\
\text { enterocolitica }\end{array}$} \\
\hline & $\begin{array}{l}\text { NCTC } \\
10460\end{array}$ & $\begin{array}{c}\text { NCTC } \\
10460 \text { SLCF }\end{array}$ & $\begin{array}{c}\text { NCTC } \\
10460 \mathrm{SBI}\end{array}$ & $\begin{array}{c}\text { NCTC } \\
10460 \mathrm{RB}\end{array}$ \\
\hline $\begin{array}{l}\text { NCTC } 1046037^{\circ} \mathrm{C} \\
\text { NCTC } 10460 \mathrm{RT} \\
\text { SLCF } 37^{\circ} \mathrm{C} \\
\text { NCTC } 1046237^{\circ} \mathrm{C}\end{array}$ & $\begin{array}{l}+\overline{+}+ \\
- \\
-\end{array}$ & $\begin{array}{l}-\overline{+}+ \\
+++ \\
+\end{array}$ & $\begin{array}{l}++ \\
+++ \\
++ \\
++\end{array}$ & $\underline{+}+$ \\
\hline
\end{tabular}

$\ldots=$ No reaction; $++=$ moderately positive reaction; $+++=$ strong positive reaction.

were made on impression preparations of all the stages in the developmental cycle, and the serological relationships between these stages were confirmed. The results of some cross reactions are shown in table II, in which it can be seen that the SLCFs cross-reacted with the parent and revertant strains, and figs. 34-39 show the serological relationships between the morphological types already described under Phase-contrast microscopy. The antiserum to $Y$. enterocolitica strain NCTC10460 was used in all the preparations from which the illustrations were taken. Tests with pre-immunisation sera were negative. Fig. 34 shows a microcolony containing stained large spheroplast L-forms and fig. 35 shows stained small coccal forms, indicating that, as in the slide-agglutination tests, these two forms, which cannot be separated, are nevertheless each serologically related to the parent form. That the large spheroplast L-forms 
stain evenly while the coccal forms stain only at the periphery may be because the latter possess a thicker cell wall as has been demonstrated by electron microscopy. Tadpole-shaped forms can be seen stained in fig. 36, and fig. 37 shows a large spheroplast L-form giving rise to a rod, indicating that these two are alike serologically; the same applies to the streptobacillus types of colonies showing filaments and spheroplast forms (figs. 38 and 39).

\section{Discussion}

The evidence presented in this paper demonstrates that a strain of $Y$. enterocolitica can pass through a developmental cycle interpretable as an L-cycle.

In this instance the L-forms described occurred without any special inducing factors and their relationship with parent and revertant bacteria is established by the evidence. Appearances suggesting the presence of L-forms within colonies examined in situ were observed, but not separate classical 'fried egg' colonies. Thus, it appears that whereas these strains of $Y$. enterocolitica are capable of producing L-forms, the rod-form is normally the dominant form under these conditions of culture.

The effect of temperature upon the reactions of $Y$. enterocolitica is welldocumented and it has now also been shown to affect the L-form. The reversion process and especially the production of tadpole-shaped forms occurred much more readily at room temperature than at $37^{\circ} \mathrm{C}$ although in fluid medium the organisms tended to remain in the SLCF regardless of temperature. They were, like the conventional rod forms, motile at room temperature but not at $37^{\circ} \mathrm{C}$, and resembled classical $Y$. enterocolitica in their Voges-Proskauer reaction, being positive at room temperature and negative at $37^{\circ} \mathrm{C}$, whereas the parent rod form was atypical, being negative at both temperatures. In all other biochemical tests the SLCF and rod-forms were identical, thereby supporting their relatedness.

Further confirmation of the relationship between the various forms described is provided by the serological tests. Agglutination, gel-diffusion and fluorescent-antibody results show relationships between the parent forms, the SLCFs, the revertant rods and another strain of $Y$. enterocolitica. Because it was not found possible to obtain small coccal forms free from large spheroplast L-forms, no conclusions could be drawn concerning differences in the antigenic structure of the different stages from small differences in cross reactions. The microscopic observations of the separate agglutination of large spheroplast L-forms and small coccal forms by the bacterial antisera and the individual staining by fluorescent antibody of the two forms (figs. 34 and 35) provided evidence that they were, in fact, each related serologically to the parent forms. The fluorescent antibody staining also demonstrated the serological relatedness of the large spheroplast L-forms to the rod forms to which they were giving rise (fig. 37).

Although the revertant forms seemed to be identical to the parent.bacteria 
in most respects, the irregular contours of the revertant bacteria (fig. 12) as compared with those of the parent organisms (fig. 10) - a phenomenon that also occurs in the Proteus L-cycle (Panchas and Schor, 1976) - may indicate a permanent ultrastructural change.

The ultrastructural studies taken in conjunction with observations on their behaviour, showed the large coccal forms to be spheroplast L-forms, rather than protoplast L-forms (Hofschneider and Martin, 1968), because they retained cell-wall material, even though they had lost rigidity. Although spheroplast L-form was the term selected, B-type L-form (Dienes and Bullivant, 1968) would have served equally well.

Further studies revealed more similarities between the large spheroplast L-forms of $Y$. enterocolitica and other L-forms studied by other workers. For example, in the forms described in this paper and in B-type L-forms of Proteus (Dienes and Bullivant, 1968), granular structures occur between the cell-wall and cytoplasmic membrane (fig. 19). Other similarities to the internal structure of the large spheroplast L-forms are apparent in the work of Green, Heidger and Domingue (1974) on group-D streptococcal L-forms. These workers published electron micrographs of sections of L-cells of the protoplast type, showing varying degrees of vesiculation, which they believed to be stages in the development of highly vesicular mother cells. They postulated that elements, several times smaller than mature mother cells, were stem cells capable of development into mother cells, of direct reversion to parental bacteria or of division by budding. Similarly, it seems that the large spheroplast L-forms of $Y$. enterocolitica can develop in the following ways: produce mother-cells (fig. 21 ), that is to say, cells containing not only membranous structures but also smaller elements which may function as elementary bodies; divide by budding (fig. 1); develop into revertant rod-forms through tadpole-shaped forms (figs. 3 and 4) or small coccal forms (fig. 2); give rise to cells resembling the mini-cells occurring in some strains of E. coli (Dennis and Rogerson, 1975), the fates of which were not determined, although some probably developed into tadpoleshaped forms, either directly (fig. 18) or through the small coccal-form stage (fig. 17); or give rise to a Streptobacillus moniliformis type of growth (fig. 8).

Membranous (figs. 20-27) and fibrillar (figs. 28-32) structures have been described in this paper and some of the former have similarities to the lamellate or mesosome-like structures seen in the L-forms of group-A streptococci (Cole, 1968; Kats et al., 1977), group-D streptococci (Green et al., 1974), E. coli (Eda, Kanda and Kimura, 1977) and Mycobacterium tuberculosis, Listeria monocytogenes, Salmonella typhi, Proteus vulgaris, Vibrio NAG and Brucella abortus (Kats et al., 1977). Eda and Kats and their co-workers believe such structures are, indeed, L-form mesosomes and it seems likely that at least some of the structures described in this paper behave as mesosomes especially because the large spheroplast forms in which they occur seem to be in an active form from which they can develop in several directions. Fig. 25, in particular, resembles the electron micrographs of Vibrio NAG and S. typhi published by Kats $e t$ al. (1977). Possibly the structure shown in fig. 22 represents a primitive type of spore. The fibrillar structures (figs. 28-32) bear superficial resemblance to the 
fibrillar and lamellate structures described by Corfield and Smith (1970) in group-A streptococcal L-forms but differ in that the fibrils are rigid, apparently solid (fig. 32) and not attached to the cytoplasmic membrane. At present, no interpretation of their composition or function can be made and it is apparent that further research is needed on L-form intracytoplasmic systems before their nature can be properly understood.

Whether the occurrence of $\mathrm{L}$-forms such as those described in this paper is a widespread phenomenon in $Y$. enterocolitica and whether they have a role in the organism's sometimes obscure role in disease processes remains to be seen.

\section{SUMMARY}

Phase-contrast and electron microscopic, serological and biochemical evidence is advanced to show that a strain of Yersinia enterocolitica can pass through a developmental cycle interpretable as an L-cycle.

I gratefully acknowledge the technical assistance of Mrs Ruth Tyler.

\section{REFERENCES}

Cole, R. M. 1968. The structure of the group A streptococcal cell and its L-form. In Current research on group A streptococcus, edited by R. Caravano, Amsterdam, p. 5.

CORFIELD, P. S. AND SMITH, D. G. 1970. Ultrastructural changes during propagation of a group D streptococcal L-form. Arch. Mikrobiol., 75, 1.

Cowan, S. T. AND Steel, K. J. 1974. Manual for the identification of medical bacteria, 2nd ed., Cambridge.

Dennis, C. A. AND Rogerson, A. C. 1975. Unusual membranous structures in minicells and minicell-producing strains of Escherichia coli. J. Bact., 124, 1610.

DiENES, L. AND Bullivant, S. 1968. Morphology and reproductive processes of the L-forms of bacteria. II. Comparative study of L-forms and Mycoplasma with the electron microscope. J. Bact., 95, 672.

EdA, T., KandA, Y. AND Kimura, S. 1976. Membrane structures in stable L-forms of Escherichia coli. J. Bact., 127, 1564.

Green, M. T., Heidger, P. M. AND Domingue, G. 1974. Proposed reproductive cycle for a relatively stable L-phase variant of Streptococcus faecalis. Infect. Immun. 10, 915.

HoFsChNeIDER, P. H. AND MARTIN, H. H. 1968. Diversity of surface layers in L-forms of Proteus mirabilis. J. gen. Microbiol., 51, 23.

Kats, L. N., Konstantinova, N. D., Shulga, M. A. and Kagan, G. J. 1977. Intracytoplasmic membrane system in bacterial L-forms. Izv Akad. Nauk. SSSR. Ser. Biol., part 1, 140 (in Russian).

LARSEN, J. H. 1976. Yersinia enterocolitica infections and arthritis. In Infection and immunology in the rheumatic diseases, edited by D. C. Dumonde, Oxford, p. 133.

Panchas, W. N. AND Schor, M. 1976. Some biologic and genetic characteristics of Proteus L-forms. In Spheroplasts, protoplasts and L-forms of bacteria, edited by J. Roux, Inserm collègue no. 64, Paris, p. 129. 